Article

\title{
A Framework of Sustainable Service Supply Chain Management: A Literature Review and Research Agenda
}

\author{
Weihua Liu *, Enze Bai, Liwei Liu and Wanying Wei \\ College of Management and Economics, Tianjin University, Tianjin 300072, China; \\ diliswatson@hotmail.com (E.B.); 18840825643@163.com (L.L.); weiwanying@tju.edu.cn (W.W.) \\ * Correspondence: lwhliu@tju.edu.cn \\ Academic Editors: Guowei Hua, T.C. Edwin Cheng, Feng Chen and Shouyang Wang \\ Received: 8 December 2016; Accepted: 7 March 2017; Published: 12 March 2017
}

\begin{abstract}
In recent years, the interdisciplinary research of supply chains and sustainability has received extensive, yet gradual, attention; when compared to the rapid economic growth of the service industry, however, sustainable supply chain management has not been systematically explored yet. It has not only great theoretical significance, but also positive practical significance to provide a framework for the operation of a sustainable service supply chain from a sustainable development point of view. Based on the triple bottom line (TBL), we have analyzed related sustainable supply chain management research between 2006 and 2015, reviewed papers involving two or three bottom lines as well, and then introduced some classical frameworks for manufacturing supply chain management and service supply chain management. Afterward, by analyzing the differences between the manufacturing and service industries, we propose a framework of sustainable service supply chain management (SSSCM). Based on the impacts of sustainable development TBL on service supply chain participants, we have finally made a framework for sustainable operation facing triads service supply chain and proposed a future research agenda.
\end{abstract}

Keywords: sustainable service supply chain; conceptual framework; literature review; research agenda; ternary relationship; triple bottom line

\section{Introduction}

Production and operations management continues to change with market conditions, which prompts enterprises to adjust their business strategies, as well. Since the 1990s, the previous enterprise-centric strategy has been replaced by a customer-centric strategy, which derived a series of emerging production and operation management techniques and methods, including Enterprise Resource Planning (ERP), Product Lifecycle Management (PLM), and Supply Chain Management (SCM). For instance, Gartner Group Inc. (Stamford, CT, USA), a renowned computer technology consulting and evaluation company in the United States, has summarized the development trend at 1990s, put forward a set of standards for enterprise management systems, and proposed ERP, which has been widely used all around the world (Powell, 2013 [1]; Beheshti et al., 2014 [2]). PLM is an important method to deal with the global product competition and uncertain market demand (Vezzetti and Alemanni, 2015 [3]). When product development is more complex, PLM is helpful in achieving visualization of product project management (Samir et al., 2004 [4]). Indeed, PLM has obtained an increasingly wide range of applications in the new product development process (Vezzetti et al., 2016 [5]).

As an important management ideology and method in production operation management, SCM is a long-standing concept. Most of the supply chain research starts with the manufacturing supply chain. 
Supply chain management first appeared in 1982. SCM is used to describe the logistic management between organizations. Its development has gone through three stages: functional management, internal management, and external integration (Master, 1994 [6]; Langley, 1992 [7]). Some top journals started to focus on service operation management in the 1990s (Aleda and Larry, 2003 [8]). Meanwhile, to deal with the problems in different scenarios, research on SCM has shifted to using a complex approach, instead of simply seeking to maximize profits or minimize costs. For example, SCM has integrated with the sustainable development concept to create many new trends in the academic field.

In 1987, the Brundtland report popularized the concept of sustainable development. (In 1983, the World Commission on Environment and Development (WCED) convened by the United Nations was created to address growing concern about the consequences of the accelerating deterioration of the human environment and the natural resources. The outcome of the work by the WCED was the report "Our Common Future". The report was quickly named the Brundtland Report in recognition of the chairman of the WCED, Gro Harlem Brundtland.) It identified the concept of sustainable development, which is meeting current development needs while not prejudicing our offspring to meet their needs. Since the Brundtland report was published, the concept of sustainable development has recently spread to various research areas, and the sustainable development of supply chain management has become a focus. With the continuous theoretical and practical expansion that began in the 1990s, green and environmental issues have begun to obtain widespread attention, and traditional supply chain management began to be evolved into the concept of sustainable development, forming sustainable supply chain management.

Sustainable supply chain management was proposed by Linton in 2007 [9]. Afterward, many scholars carried out related studies. Some researchers have defined the term sustainable supply chain from the level of management and economic profit, including Seuring and Mueller (2008) [10], and Carter and Roger (2008) [11]. Recently, research on supply chain management has also shifted from a reverse or close-loop supply chain to a green supply chain or sustainable supply chain management based on triple Bottom Line (TBL). TBL is an integration concept of economic bottom line, environmental bottom line and social bottom line. Nowadays, with the consideration of TBL, the focus of sustainable service supply chain management (SSSCM) has become to optimize the whole service supply chain's economy, environment, and social performance.

At the same time, during the economic globalization process, the service industry has increased quickly, and its contribution to economic growth is increasingly obvious. Ellram (2004) [12] has defined service supply chain, which refers to a new supply chain, including information management, process management, competency management, service performance, and treasury management that occurs in professional services, from the upper stream supplier to the downstream customer. Nowadays, the definition of service supply chain has been extended, which includes Service Only Supply Chains (SOSCs) and the Product Service Supply Chains (PSSCs) (Wang et al., 2015) [13]. In the aspect of SOSCs, Baltacioglu et al. (2007) [14] define a service supply chain system as "a network of suppliers, service providers, consumers, and other supporting units that performs the functions of transactions of resources required to produce services; transformation of these resources into supporting and core services; and the delivery of these services to customers". Demirkan and Cheng (2008) [15] define an application service supply chain as a system composed of three parties: the service producer for infrastructure, the retail service provider, and the customer. In the real world, these kinds of service supply chains can be found in industries such as finance, telecommunication, Internet service, mobile apps, and tourism. In the aspect of PSSCs, many PSSCs manage physical products together with significant service considerations. Thus, there are both "services" and "physical products" in these supply chain systems. Arguably, there are more PSSCs than SOSCs explored in the literature. For example, we can find PSSCs in restaurant and food retail supply chains, product design and retailing supply chains, logistics service supply chain, and hotel supply chain (Sampson and Spring, 2012 [16]; Wang et al., 2015 [13]; Liu et al., 2016 [17]). However, whether in PSSC or SOSC, a service 
integrator provides customized services to customer by integrating the service capacities of multiple functional service providers.

The global popularization of service outsourcing also has pushed the rise of the service supply chain (Hussain et al., 2015 [18]; Baltacioglu et al., 2007 [14]). However, due to the specific characteristics of service, including labor intensity, intangibility, and inseparability, subsequent problems have arisen. The constraints made by economics, the environment, and society, that is, the triple bottom line on the development of the service supply chain becomes increasingly prominent. The conflicts among environmental overconsumption, increasing social problems, and a low-profit operation model have restricted the sustainable development of the service supply chain. This situation is particularly evident in developing countries. Take the environment, for example: in a regional emission check of transportation vehicles in China's logistic service supply chain, there were 17 logistics service providers and 78 logistics service vehicles in total that exceeds the emission standards. It accounts for about $10 \%$ of the total number of checked vehicles [19]. These bad vehicles caused environmental pollution. As for the social aspect, in the hotel service supply chain, China's hotel industry frequently reported some negative news in 2016, for example, the news entitled "Fast hotel washed out white bed sheets with caustic soda blending detergent", has caused consumer concerns. This negative news indicates that the core firm of the hotel service supply chain has lost its social responsibility [20]. From an economics aspect, consider the tourism service supply chain, for instance: in September of 2016, China's well-known travel service integrator Youke tourism company filed for bankrupt, due to a default in the payment for suppliers about 17 million Yuan, which led to its capital chain break [21]. Nevertheless, in November, another travel service integrator, the Chiyu tourism company, announced that its capital chain broke. One important reason for the capital chain breakage is that these service integrators' management is too worse to lack the sustainability philosophy so that the companies' profit is lower than the safe operation margin. The importance of research regarding the sustainable service supply chain becomes increasingly prominent, yet the related literature is rare, a framework of SSSCM is scarcer. This obvious gap is the motivation of our research.

Based on this, we review related papers in 2006-2015, use TBL to summarize those studies, propose a new framework for the SSSCM by combining existing supply chain research, and then provide a new research direction for future work.

\section{Methodology}

We used the paper review method proposed by Mayring (2003) [22] to summarize the existing research in 2006-2015, then we identified and chose papers based on this summary. The concrete steps are as follows: (1) source identification; (2) source selection and extraction; and (3) source evaluation and categories generation (Reim et al., 2015 [23]; Agrawal et al., 2015 [24]), as shown in Figure 1.

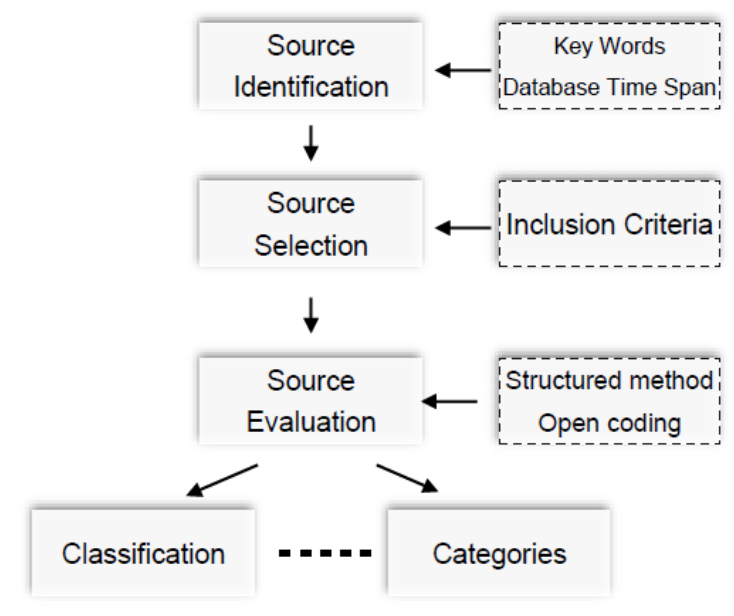

Figure 1. Strategic steps of review. 
The first step is source identification, which aims to select the literature related to our purpose and method. Therefore, this step should identify three main points: the source, keyword (if needed), and time distribution. Although the key words cannot fully capture all of the studies, the key words for obtaining the relevant areas of the main research is very helpful. According to the principle most relevant to this study, we used sustainable + supply chain to search for headings and abstracts, but we must note that, even though some studies may show sustainable + supply chain in the abstract or keyword section, the research topics of these studies are irrelevant and we removed them. For example, some research topics also discussed sustainable supply chain but focus on chemical reaction or design in supply chains in the research fields such as chemistry, electrochemistry, biochemistry, etc. so these studies have to be removed. The entire research process focuses only on journal articles, so conference papers, working papers, commentaries, and book reviews are not included (Reim et al., 2015 [23]). In addition, the most commonly used academic databases are used during our study: Web of Science, Emerald, ProQuest Central, ScienceDirect, Wiley, and Taylor \& Francis online (Reim et al. [23], 2015; Agrawal et al., 2015 [24]; Lotfizadeh et al., 2014 [25]; Seuring, 2008 [26]). These databases include multidisciplinary, peer-reviewed academic literature. In fact, these databases include mainstream research journals in the field of sustainable supply chains, in particular, top-level operational management journals, such as Omega, International Journal of Production Economics, International Journal of Production Research, and European Journal of Operational Research. At the same time, there are a number of journals that consider sustainability, such as Sustainability, Computers and Chemical Engineering, Renewable, and Sustainable Energy Reviews, which have also been taken into consideration.

Although sustainability and supply chains both have a long history of research in their own fields, a crossover study actually began in the early 21 st century. Carter and Rogers made a relatively clear definition of sustainable supply chain management in 2008, defining it as the long-term economic benefits of the supply chain in which firms and enterprises are located, coordinating cross-organizational core business processes, and social, environmental, and economic objectives of the strategic and transparent integration and implementation. Based on our literature review, most of the studies on sustainable supply chain management have taken place in the last 10 years. As the first step, considering the goals of guiding future research and exploring new sustainable management frameworks, this paper selects papers published between 2006 and 2015, a total of 10 years, as the time span of our literature review. According to the source selection method shown in Figure 1, Table 1 provides the number of original documents chosen.

Table 1. The Number of original documents for each database.

\begin{tabular}{cc}
\hline Database & Initial Identified \\
\hline Web of Science & 2197 \\
Emerald & 93 \\
ProQuest Central & 762 \\
ScienceDirect & 4364 \\
Wiley & 278 \\
Taylor \& Francis & 207 \\
Total & 7901 \\
\hline
\end{tabular}

According to Table 1, three researchers read these original documents. If the topic or abstract of the literature has no obvious relationship with sustainable supply chain management, the document should be removed from the list. The excluded documents at this step are 2698 papers; the rest of the literature is comprised of 5203 papers.

The second step is resource selection and extraction. This step is designed to extract the target literature from the literature retrieved in the first step. Subject to the scope of the study, only studies with strong or direct links to the sustainable supply chain will be selected. Therefore, the inclusion criteria (Mayring, 2003 [22]; Seuring, 2008 [26]) are shown below: 
- It clearly discusses the sustainability of the supply chain including the explicit use of conceptual or empirical research to study the impact on supply chain sustainability. The explicit use means its theme has words "sustainable", "supply chain" or "supply network", for example, Kannegiesse et al., 2015 [27].

- It implicitly discusses the sustainability of the supply chain, including implicitly articulating research on the value and perspective of supply chain sustainability. The implicit use means its theme does not have words "sustainable", "supply chain" or "supply network" but the content are related with sustainable supply chain, for instance, Helin and Babri, 2014 [28].

Three researchers spent 3 months reading the rest of the literature, in accordance with the above criteria. By checking the content in Table 1, we further excluded 4405 papers that are unrelated, such as some chemical reactions (1977 papers), biological experiments (1065 papers), science and technology (873 papers), and other areas (490 papers). We eliminated articles that did not directly contribute to the sustainable supply chain management framework. The results are shown in Table 2 . The number of papers after elimination is 798 .

Table 2. The number of papers after the first filtration.

\begin{tabular}{cc}
\hline Database & Initial Identified \\
\hline Web of Science & 179 \\
Emerald & 23 \\
ProQuest Central & 86 \\
ScienceDirect & 389 \\
Wiley & 85 \\
Taylor \& Francis & 36 \\
Total & 798 \\
\hline
\end{tabular}

The third step is source evaluation. Among the various definitions of sustainable development, the most central idea is that of the TBL approach, proposed by Elkington in 2002. The triple bottom line theory refers to the enterprise's three responsibilities, namely, economic responsibility, environmental responsibility, and social responsibility. These three responsibilities constitute the bottom line of enterprise development. Economic responsibility is the traditional corporate responsibility, mainly to improve profits, tax liability, and shareholder dividends for the shareholders. Environmental responsibility refers to environmental protection. Social responsibility is the responsibility to other stakeholders in society. Enterprises in the practice of corporate social responsibility must fulfill these three areas of responsibility. Most studies on SSCM are conducted based on TBL and many involve two or more bottom lines (Seuring and Mueller, 2008 [10]). Therefore, our screening criterion also considers the TBL when we construct a sustainable supply chain management framework. As a result, 101 articles have been selected for our research; the spread of the database is shown in Table 3. Those articles are distributed in major journals, as shown in Table 4. It could be found that the total number of articles in Table 3 is 248, which is larger than 101, that is, the total number of articles in Table 4. The reason behind this phenomenon is that one paper could be covered in different databases. Figure 2 shows the time spread of those papers. In Figure 3, we can see that 91 of the ultimately identified articles contain environmental responsibility and economic responsibility, 23 contain economic responsibility and social responsibility, 21 contain environmental responsibility and social responsibility, and a total of 17 articles contain all three aspects of responsibility. 
Table 3. The Number of papers in databases after the second filtration.

\begin{tabular}{cc}
\hline Database & Ultimately Identified \\
\hline Web of Science & 101 \\
Emerald & 31 \\
ProQuest Central & 28 \\
ScienceDirect & 53 \\
Wiley & 18 \\
Taylor \& Francis & 17 \\
Total & 248 \\
\hline
\end{tabular}

Table 4. The Number of papers covered in major journals.

\begin{tabular}{cc}
\hline Journal & Numbers \\
\hline International Journal of Production Economics & 23 \\
Sustainability & 18 \\
Renewable and Sustainable Energy Reviews & 6 \\
International Journal of Life Cycle Assessment & 10 \\
International Journal of Production Research & 9 \\
Energy & 8 \\
Omega & 7 \\
European Journal of Operational Research & 9 \\
Journal of Clean Production & 8 \\
Computers and Chemical Engineering & 3 \\
Total & 101 \\
\hline
\end{tabular}

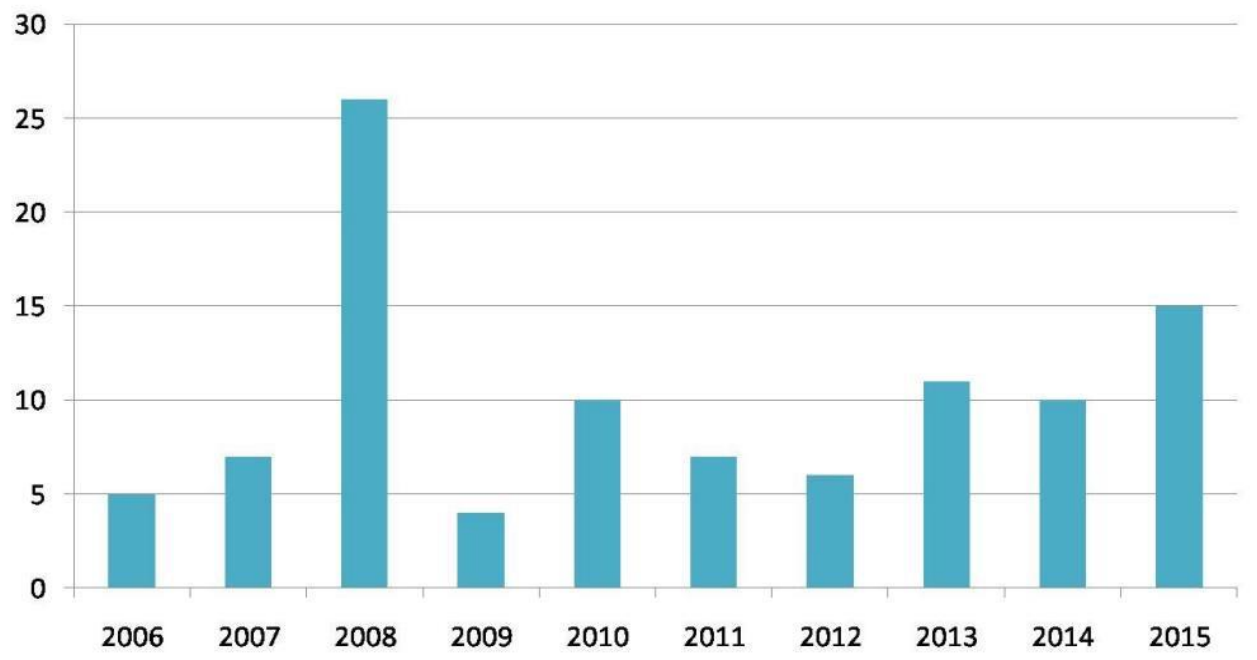

Figure 2. Time span of journals. 


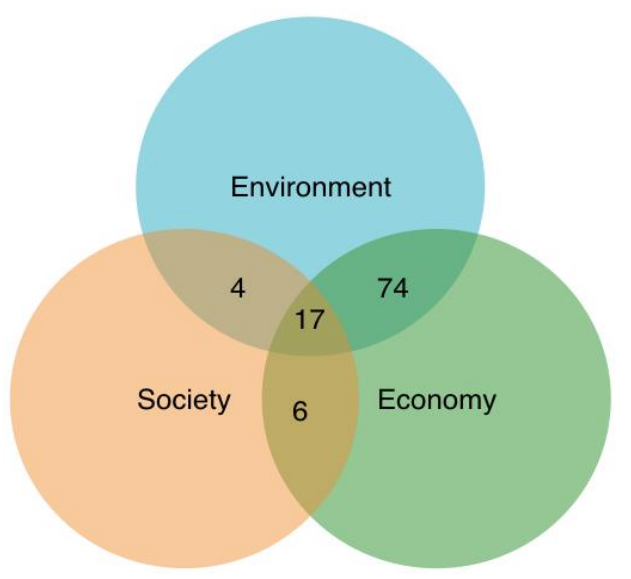

Figure 3. Final filter result when considering Triple Bottom Line.

\section{Research Analysis}

Service supply chains and manufacturing supply chains both belong to the field of supply chains. However, in the existing literature, supply chain management in the manufacturing industry is far more studied than supply chain management in the service supply chain (Aleda and Larry, 2003 [8]; Seuring and Mueller, 2008 [10]; Wang et al., 2015 [13]). Some researchers state the reasons that there are differences between service supply chain and manufacturing supply chain (Sengupta et al., 2005 [29]; Zhou et al., 2009 [30]). However, there still exist similarities and relations between service and manufacturing supply chain. Many studies in service supply chain have been inspired by these similarities and relations and made new explorations. For example, Anderson et al. (2005) [31] analyzed the bullwhip effect in a service supply chain, deriving from studies of make-to-stock manufacturing supply chains. Wei et al. (2013) [32] studied a two-stage game problem on pricing, ordering and allocation in a service supply chain on the basis of news vendor model of manufacturing supply chain. Liu et al. (2017) [33] developed a conceptual model of the influence of control power on the performance of service supply chains, based on the modeling method from manufacturing supply chain. Therefore, many sustainable supply chain management methods in the manufacturing industry are very helpful in exploring the sustainable service supply chain research. In this section, we will analyze those chosen papers. From a sustainable and supply chain management point of view, we will review papers considering two or three bottom lines, and then we will propose a framework of SSSCM.

\subsection{Sustainable Supply Chain Management: Environment and Economy Point of View}

Since the 1980s, global warming has brought attention to environmental problems, which enhanced the concept of sustainable development. In 1994, Murphy [34] proposed a research about sustainable development that environment and economy were both considered. In 2008, Britain officially approved and applied the Climate Change Act by Congress, which made Britain the first country in the world with a long-term framework of legal binding aimed at reducing greenhouse gas emissions in order to adapt to climate change. Consequently, Britain has kept a watchful eye on chemical and biological engineering recently. With more and more global competition, corporate operations have been facing more environmental responsibility, making the integration of environmental and economic factors for supply chain management more important (Ferdows, 2009) [35]. Since the 21st century, the growing attention on the environment has contributed to the emerging design of the environmental supply chain network, namely, the supply chain design with facilities, transportation, progress, process, technic, and progress-synthesizing environmental factors concerned.

There have been many methods in the view of environmental and economic sustainable supply chain management to decide the sustainable development of supply chains, such as operational 
research models, the Life Cycle Assessment, Inference Graph, Analytic Hierarchy Process, Network Analysis, and Data Envelopment Analysis, as well as the Equilibrium Model and Simulation (Seuring, 2013) [36]. For instance, in the operational optimization model, You and Wang (2011) [37] applied MLTP (Multiphase-mixed Linear Programming) mixed with LCA (Life cycle assessment) into the British chemical and biological fuel. The results showed that the environmental performance of a chemical and biological fuel supply chain under a circular economy has been much better than the traditional supply chain. In the end, Genovese (2015) [38] pointed out that it may need government support from bottom to top to motivate the implementation of a circular economy for supply chain participants from top to bottom.

Regarding the environment and economy, many papers have discussed SSSCM. For example, Hasan (2013) [39] found that the environment gains general attention on the service supply chain operation level. One of his cases is Westpac Bank in Australia, which is the focal company in the service supply chain; it requires its suppliers to accept continuous improvement and cooperation methods, such as managing their environmental impact and dealing with atmospheric issues. Hasan also thought that an improvement in areas such as recycle packaging techniques and good cooperation with suppliers would decrease the supply chain cost and enhance the risk control and service innovation.

However, many studies do not explicitly distinguish between service and manufacturing supply chains. Taking Omer (Omer, 2007) [40] as an example, he analyzed the relationship between renewable energy, environment performance, and sustainable development from the perspective of the present and the future. He noted that, in order to reach environmental efficiency and economic efficiency, it is necessary to make related training and information transmission in supply chain sustainable construction to obtain the sustainable performance of supply chains. Brandenburg et al. (2014) [41] summarized the quantitative model of the sustainable development supply chain. They have systematically reviewed the environmental factors taken into consideration and how to quantify and integrate these factors into mathematical optimization models.

\subsection{Sustainable Supply Chain Management: Society and Environment Point of View}

Sustainability, in a social aspect, mostly stresses quality and human rights; focuses on analyzing labor conditions, practice and social welfare; supplier's adhering to the laws and regulations; etc. (Beske et al., 2014) [42]. In 2008, SAI proposed SA8000 (SAI, 2008) [43] to focus on the social dimension; however, it was barely used by corporations, due to difficulties in practice. ISA26000 (European Commission, 2009) [44] made up for this defect by presenting an evaluation framework considering both the environment and society, and applied it in practice gradually. Carroll (1979) [45], Clarkson (1995) [46], and Wood (1991) [47] first put forward social responsibility and a set of evaluation criteria to clarify the concept of social responsibility. With the rising of the sustainable supply chain, the business with a more effective social and environmental response became more competitive, which pushed the implementation of green supply chain management (GSCM), including green design, green procurement, clearer production, waste minimization, life cycle cost accounting, and so on (Berry and Rondinelli, 1998) [48]. Those green supply chain activities are of great importance to sustainable development.

As the criteria of society and the environment are usually abstract and unspecific, previous studies are mostly focused on case analyses and paper reviews, such as those of Azapagic and Perdan (2000) [49], Carter and Jennings (2002) [50], Hutchins and Sutherland (2008) [51], Matos and Hall (2007) [52], O'Connor and Spangenberg (2008) [53], Foerstl et al. (2010) [54], and Gimenez et al. (2012) [55].

Gimenez et al. (2012) [55] presented a classical case analysis in the manufacturing supply chain. In their research, Gimenez et al. (2012) [55] studied empirical cases about how environmental and social activities would affect all aspects of TBL in supply chain coordination. Their study shows that environmental activities have a positive effect on TBL and inner social activities have a positive 
effect on the two aspects of society and environment; however, there is a negative effect on the cost of manufacturers.

There are also articles using mathematical modeling to explore sustainable supply chain management from the social and environmental perspective, for example, Castka and Balzarova (2008) [56], Rubio and Corominas (2008) [57], Tseng (2009) [58] and Eskandarpour (2015) [59], among which, Eskandarpour's (2015) [59] is a very systematical paper. He has sorted out mathematical modeling methods focusing on the optimization of society and the environment. He pointed out that, from the operation perspective, the network design of the supply chain aims to decide the best location, scale, and process. Although there are multiple models on logistic network problems barely involving sustainable development, especially considering the supply chain profit share from the society aspect. In the social and environmental supply chain performance models, as a mainly comprehensive appraisal framework, LCA is a frequently used method in the optimization model. Environmental LCA usually uses carbon footprint as an evaluation criterion, while social LCA can help make decisions when considering the effect on society of products (Jorgensen, 2013) [60]. In the future, research on the environmental and social sustainable supply chain should try to put forward a new LCA mixed I-O (such as Materials Flow Analysis), based on the progress method.

In their research of service supply chains, Grimm et al. (2014) [61] could be representative of a case study; they focus on a food supply chain with a two-case analysis. They state that there are four social- and environmental-related factors significantly correlated with the relationship management of secondary upstream suppliers. As for mathematical research, the study by Ramos et al. (2014) [62] could be representative. They use a multi-objective and multistage planning model, especially considering factors such as the service area, path setting and planning, carbon dioxide emission, and human resource working time in the reverse logistics service supply chain. Finally, they provide a separate solution for the sustainable logistics service supply chain.

\subsection{Sustainable Supply Chain Management: Society and Economy Point of View}

Although there is an increasing application of ISO26000 in the social responsibility aspect, the research of sustainable supply chain management in the social aspect is less pronounced than it is in the two other aspects. Similar to Clarkson (1995) [46] and Wood (2015) [63], most of the articles that first illustrated the concept of social responsibility simply described it as well as its set of assessment criteria. Hahn(2013) [64] pointed out that the effects of social criteria on economic profit are still limited because the social criteria were presented indirectly. However, more researchers are currently focusing on this area.

From the social and economic point of view, the studies on manufacturing supply chains are relatively older or vaster. In 2012, Mori and Christodoulou [65] described the commends of the City Sustainability Index (CSI) based on a series of ecological footprint, human development, and genetic engineering criteria, which can help researchers to set up a more comprehensive sustainable framework. Chen et al. (2014) [66] thought that, for the difference in culture and ethics values, Corporate Social Responsibility (CSR) should be seriously considered in the process of global manufacture network development. In the long term, both social benefit and economic profit need to meet the sustainable development of supply chains and, at the same time, meet human needs. For instance, in order to apply social responsibility and satisfy the balance between economic and social profit in supply chain management, we need to be concerned about the rights and interests of employees, stress the co-development of upstream and downstream firms in supply chains (Ciliberti et al., 2008) [67], and pay attention to public welfare activities.

From the two aspects of society and economics, the current research on the sustainable management of service supply chains is limited. In 2015, Hussain [18] proposed a service sustainable supply chain framework in Arabic, based on CFA (Confirmatory Factor Analysis), which considered the effects of social responsibility on supply chain performance, providing a new research angle of sustainable supply chain management. 


\subsection{Sustainable Supply Chain Management: Environment, Society, and Economy Point of View}

During our research, we found that the integration of the triple bottom line in sustainable development theoretical research is very scarce. In order to make our sustainable supply chain operation framework more reasonable, we further studied the articles that addressed the sustainable problems based on TBL and proposed the conceptual frameworks from the filtered 101 papers mentioned above. The screening criteria are as follows:

- The triple bottom line in the sustainable supply chain is explicitly discussed.

- A clear operational or regulatory framework for a sustainable supply chain is presented, including a framework that provides a valuable perspective and theoretical research on supply chain sustainability.

As shown in Figure 3, based on the above screening criteria, there are 17 mostly qualitative articles (Seuring, 2008 [26]; Hassini et al., 2012 [68]; Wu and Pagell, 2011 [69]; Ageron, 2012 [70]; Beske, 2014 [42]; Brandenburg, 2015 [71]).

Regarding the aspect of qualitative manufacturing supply chain research, Chardine-Baumann [72], in 2014, has used the analytical method of compound factor to propose an evaluation framework of sustainable performance, which could be used to identify the best quality of supply chain performance. He also pointed out that whether optimized economic profit equals to best environmental and social profit should be analyzed through this evaluation framework. However, some scholars do not clearly distinguish between the service and manufacturing supply chain; for instance, Seuring (2008) [26] has put forward the framework of supply chain management of sustainable products by a literature review.

Regarding the aspect of qualitative service supply chain research, based on the triple bottom line theory, Beske (2014) [42] combined dynamic capability with sustainable supply chain management to construct sustainable performance in the food supply chain. Meanwhile, based on an empirical study of the food supply chain, he confirmed the existing potential synergies between innovation and sustainability.

Regarding the aspect of quantitative service supply chain research, some researchers also made contributions (Hussain, 2015 [18]; Winkler, 2011 [73]). For the manufacturing supply chain, Amini (2014) [74], Ageron (2011) [70], and Wu et al. (2011) [69] presented sustainable supply chain management frameworks based on TBL. For example, Wu et al. (2011) [69] studied how organizations make decisions to balance short-term returns and long-term environmental sustainability in uncertain situations. Amini (2014) [74] suggested that there is a potential synergy between sustainability and innovation in the behavior of corporations. Ageron (2011) [70] has proposed a framework for sustainable operations and validated it by empirical studies.

For a service supply chain in the quantitative aspect, Brandenburg (2013) [71] reviewed sustainable supply chain management papers from a modeling aspect, showing that the future research direction of sustainable supply chain management should integrate the pressures and incentives generated by external stakeholders, which has provided the criteria for sustainable supplier management and sustainable risk management.

We analyzed and sorted those 17 papers systematically, and the result is shown in Table 5 . 
Table 5. Sustainable supply chain management based on TBL.

\begin{tabular}{|c|c|c|c|c|c|}
\hline Authors & Year & Type & Journal Title & Research Field & Main Conclusion \\
\hline $\begin{array}{l}\text { Hussain, Khan, } \\
\text { and Al-Aomar }\end{array}$ & 2015 & Quantitative & $\begin{array}{l}\text { Renewable and Sustainable } \\
\text { Energy Reviews }\end{array}$ & S & $\begin{array}{l}\text { Use sustainable view to build and design their network for managers, } \\
\text { from providers to customers. }\end{array}$ \\
\hline $\begin{array}{l}\text { Cassini, Surti, } \\
\text { and Searcy }\end{array}$ & 2012 & Qualitative & $\begin{array}{l}\text { International. Journal of } \\
\text { Production Economics }\end{array}$ & $\mathrm{M} / \mathrm{S}$ & Presentations of a sustainable supply chain unique concept. \\
\hline Wu and Pagell & 2011 & Qualitative & $\begin{array}{l}\text { Journal of Operations } \\
\text { Management }\end{array}$ & M & $\begin{array}{l}\text { In the uncertain case, how organization make supply chain decisions } \\
\text { when balancing short-term gains and long-term environmental } \\
\text { sustainability. The article found that business managers when making } \\
\text { environmental factors decisions will consider the short-term benefits. }\end{array}$ \\
\hline Winkler & 2011 & $\begin{array}{l}\text { Quantitative and } \\
\text { Qualitative }\end{array}$ & $\begin{array}{l}\text { CIRP Journal of Manufacturing } \\
\text { Science and Technology }\end{array}$ & M & $\begin{array}{l}\text { Proposed the concept of a sustainable supply chain network } \\
\text { closed-loop manufacturing system, as well as four steps for success. }\end{array}$ \\
\hline $\begin{array}{l}\text { Chaabane, Ramudhin, } \\
\text { and Paquet }\end{array}$ & 2010 & $\begin{array}{l}\text { Quantitative and } \\
\text { Qualitative }\end{array}$ & $\begin{array}{l}\text { International. Journal of } \\
\text { Production Economics }\end{array}$ & M & $\begin{array}{l}\text { This paper uses a framework based on mixed integer linear } \\
\text { programming to consider the sustainable supply chain life cycle } \\
\text { assessment. An effective carbon management strategy can help } \\
\text { decision makers achieve a cost-effective sustainability goal. }\end{array}$ \\
\hline Gupta, and Omkar & 2011 & Qualitative & IIMB Management Review & M & $\begin{array}{l}\text { A general framework is proposed, showing that the existing studies } \\
\text { focuses on four broad aspects: } 1 \text { Strategic considerations } 2 \text { Functional } \\
\text { level decisions } 3 \text { Laws and regulations } 4 \text { Integral models and decision } \\
\text { support tools. }\end{array}$ \\
\hline Securing and Muller & 2008 & Qualitative & Journal of clean production & $\mathrm{M} / \mathrm{S}$ & $\begin{array}{l}\text { This paper discusses the barriers to supply chain sustainability from } \\
\text { the perspective of sustainable external factors in the service supply } \\
\text { chain, and provides a conceptual framework to illustrate how to } \\
\text { manage the supplier's risk and performance. }\end{array}$ \\
\hline $\begin{array}{l}\text { Peano, Tecco } \\
\text { and Dansero }\end{array}$ & 2015 & $\begin{array}{l}\text { Quantitative and } \\
\text { Qualitative }\end{array}$ & Sustainability & S & $\begin{array}{l}\text { A conceptual framework for sustainable assessment of small fresh } \\
\text { agricultural supply chains has been proposed and validated with ten } \\
\text { small fresh agricultural products systems. It was confirmed that the } \\
\text { conceptual framework could be used for sustainable prediction of } \\
\text { fresh agricultural product supply chain. }\end{array}$ \\
\hline $\begin{array}{l}\text { Brandenburg } \\
\text { and Rebs }\end{array}$ & 2015 & $\begin{array}{l}\text { Quantitative and } \\
\text { Qualitative }\end{array}$ & Annals of Operations Research & $\mathrm{M} / \mathrm{S}$ & $\begin{array}{l}\text { There are vacancies in SCM models regarding pressure and motivation } \\
\text { as well as risk and supplier management. }\end{array}$ \\
\hline $\begin{array}{l}\text { Tseng and } \\
\text { Divinagracia }\end{array}$ & 2015 & $\begin{array}{l}\text { Quantitative and } \\
\text { Qualitative }\end{array}$ & $\begin{array}{l}\text { Industrial Management and } \\
\text { Data Systems }\end{array}$ & $\mathrm{M}$ & $\begin{array}{l}\text { The first consideration in the sustainable environment should be the } \\
\text { stakeholder indicators, followed by green design, cooperative } \\
\text { sustainability, environmental management strategy design, cost-saving } \\
\text { supplier motivation and market share. }\end{array}$ \\
\hline
\end{tabular}


Table 5. Cont.

\begin{tabular}{|c|c|c|c|c|c|}
\hline Authors & Year & Type & Journal Title & Research Field & Main Conclusion \\
\hline $\begin{array}{l}\text { Ageron, Spalanzani, } \\
\text { and Gunasekaran }\end{array}$ & 2011 & Qualitative & $\begin{array}{l}\text { International Journal of } \\
\text { Production Economics }\end{array}$ & $\mathrm{M} / \mathrm{S}$ & $\begin{array}{l}\text { A conceptual framework for a sustainable supply chain is constructed } \\
\text { and verified with examples (in the French region). }\end{array}$ \\
\hline $\begin{array}{l}\text { Beske, Land, } \\
\text { and Seuring }\end{array}$ & 2013 & Qualitative & $\begin{array}{l}\text { International Journal of } \\
\text { Production Economics }\end{array}$ & $\mathrm{M} / \mathrm{S}$ & $\begin{array}{l}\text { Applications of SSCM help companies continue to control their entire } \\
\text { supply chain, and provide competitive advantage. }\end{array}$ \\
\hline $\begin{array}{l}\text { Aminia, Carol } \\
\text { and Bienstockb }\end{array}$ & 2014 & $\begin{array}{l}\text { Qualitative and } \\
\text { Quantitative }\end{array}$ & $\begin{array}{l}\text { Journal of } \\
\text { Operations Management }\end{array}$ & M & $\begin{array}{l}\text { Based on literature review, this paper has drawn a conclusion on the } \\
\text { sustainable behavior and framework of the tangible business, } \\
\text { discovered the potential synergies between sustainability } \\
\text { and innovation. }\end{array}$ \\
\hline $\begin{array}{l}\text { Chardine-Baumann } \\
\text { and Botta-Genoulaz }\end{array}$ & 2014 & Quantitative & $\begin{array}{l}\text { Computers and } \\
\text { Industrial Engineering }\end{array}$ & M & $\begin{array}{l}\text { This paper has considered all three aspects of sustainability (total cost, } \\
\text { GHG emissions and lead time), and proposed an optimal framework } \\
\text { for multi-objective scenarios to optimize the sustainable supply chain. }\end{array}$ \\
\hline $\begin{array}{l}\text { Brandenburg } \\
\text { and Rebs }\end{array}$ & 2015 & Qualitative & Annals of Operations Research & $\mathrm{M} / \mathrm{S}$ & $\begin{array}{l}\text { This paper summed up quantitative research on sustainable supply } \\
\text { chains and found vacancies for future research. }\end{array}$ \\
\hline
\end{tabular}




\section{Sustainable Supply Chain Operation Framework}

Although the studies of manufacturing supply chain have matured, there are still some shortcomings in the sustainable research of the service supply chain. Hence, we start with the manufacturing supply chain sustainable framework in Section 4.1, and then discuss the service supply chain sustainable framework by analyzing the difference between service industry and manufacture in Section 4.2.

\subsection{Manufacture Supply Chain Sustainable Framework}

Sustainable operation of the manufacturing supply chain is often related to the internal structure of the supply chain and the external environment. Brandenburg, in 2015 [71], summed up the sustainable supply chain management from the mathematical modeling point of view and proposed a manufacturing supply chain sustainable framework. Ageron, in 2011 [70], based on empirical evidence, through the external economic transformation and the global market point of view, proposed a framework for the operation of sustainable supply chains.

As showed in Figure 4, Brandenburg [71] thought that focal firms are connected to providers and customers through products and processes, and there are different stakeholders outside the supply chain, such as government and public opinion, whose pressure or motivation magnifies the impact of sustainable supply chain management, including customer management and sustainable risk management. Consistent with the TBL, these sustainable practices are designed to achieve three objectives of sustainability: economic, social, and environmental performance. Meanwhile, objectives always have a win-win relationship, i.e. could ensure minimum environmental and social performance requirements.

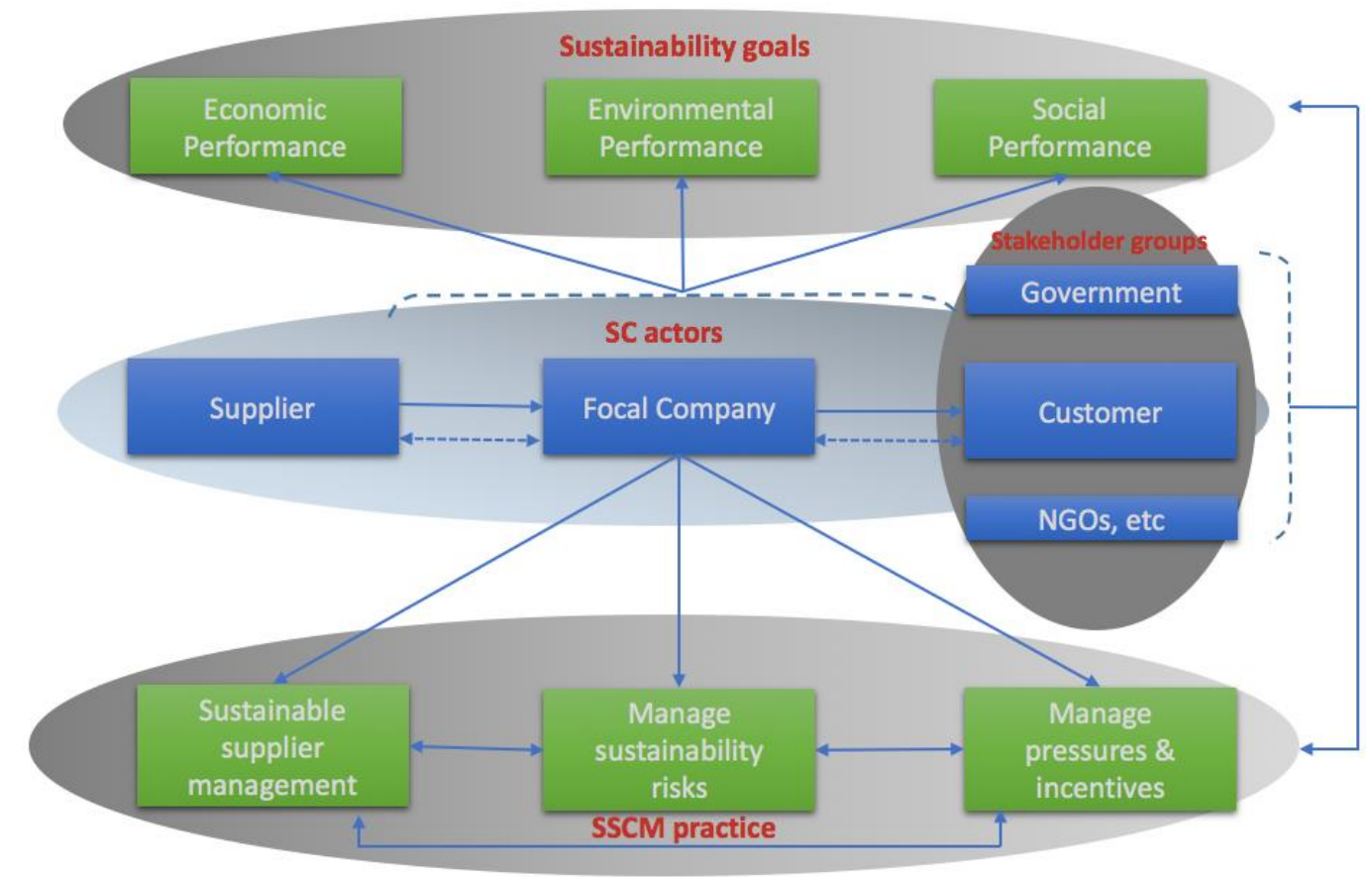

Figure 4. Manufacturing supply chain sustainable framework (Brandenburg, 2015 [71]).

Ageron [70] proposed that sustainable supply management includes seven modules, namely, reasons, standards, the green supply chain, supplier characteristics, the SSM approach to management, resistance, and profitability and motivation.

In addition, Carter and Rogers (2008) [11] also present a framework of sustainable supply chain based on resource dependence theory, transaction cost economics, population ecology, and the 
resource-based view of the firm, which could be seen in Figure 5. Amini (2014) [74], however, different from Brandenburg (2015) [71] and Ageron (2011) [70], divides the sustainability of an enterprise's supply chain into five dimensions, based on sustainable complex maturity, namely, Business Level Application and Communication, Scope of Organization Focus, Sustainability-Oriented Innovation, Economic/Ecology-Environmental/Equity-Social Emphasis, and Compliance Stance. If a corporation shows good performance in those five dimensions, such as zero pollutant emissions, a good public image, comprehensive supply chain information, a willingness to share, etc., then Amini thought that this corporation was highly sustainable.

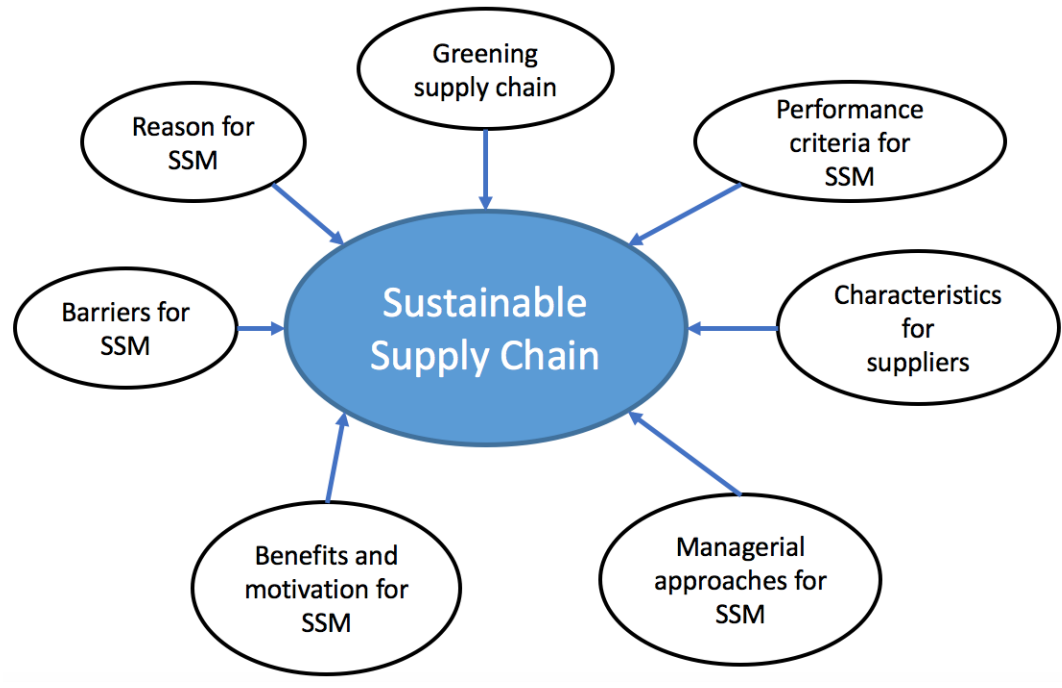

Figure 5. Manufacture sustainable supply chain management conceptual model (Ageron, 2011 [70]).

\subsection{Service Sustainable Supply Chain Framework}

We can see in Table 5 that most existing research on sustainable supply chain operation frameworks are about the manufacturing supply chain, while there is limited research on the service supply chain, let alone those service sustainable supply chains that simultaneously consider the environment, economy, and society. However, there have been two types of classical frameworks in service sustainable supply chain research, that is, Hussain et al. (2015) [18] and Seuring and Mueller (2008) [26]. Based on empirical research, Hussain et al. (2015) [18] have studied how companies can remain productive and profitable while ensuring sustainability. Based on the criteria of TBL and relying on the service supply chain in the Abu Dhabi region, such as cafeterias, aviation, and hospitals, the questionnaire and the confirmatory factor analysis have been used to obtain the limited service supply chain sustainable framework, as shown in Figure 6. He believes that the sustainability of the service supply chain can be composed of four dimensions. Environmental management is the primary indicator of sustainable practices, followed by social responsibility, customer management and health, and safety and risk management, sequentially. 


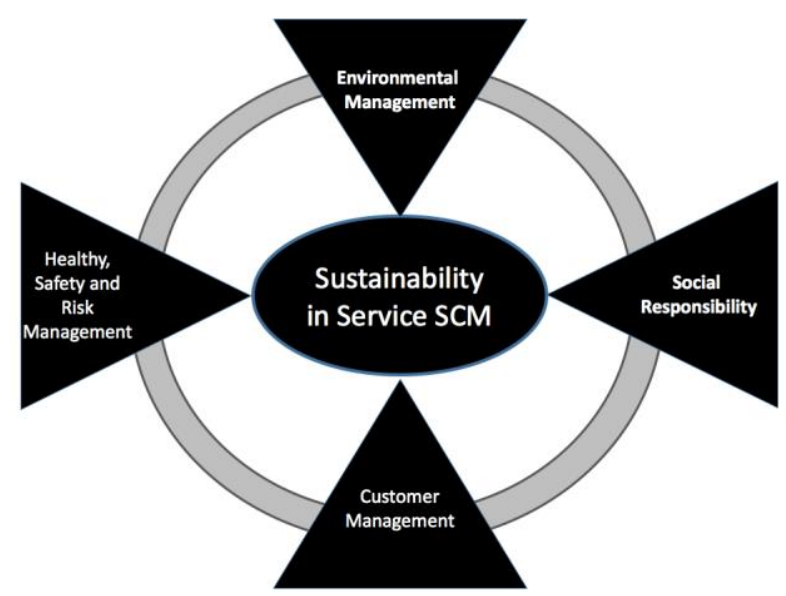

Figure 6. Framework of Service Sustainable Supply Chain (Hussain et al., 2015 [18]).

In addition to the empirical studies above, some scholars use the literature review method for sustainable supply chain operation framework in the service industry.

For example, Seuring (2008) [26] has discussed the barriers to supply chain sustainability from the perspective of sustainable external factors in the supply chain, which are mainly embodied in three aspects: a high cost, coordinated effort and complexity, and lack of communication between groups. He then provided a conceptual framework for improving supply chain performance and reducing risk, as shown in Figure 7.

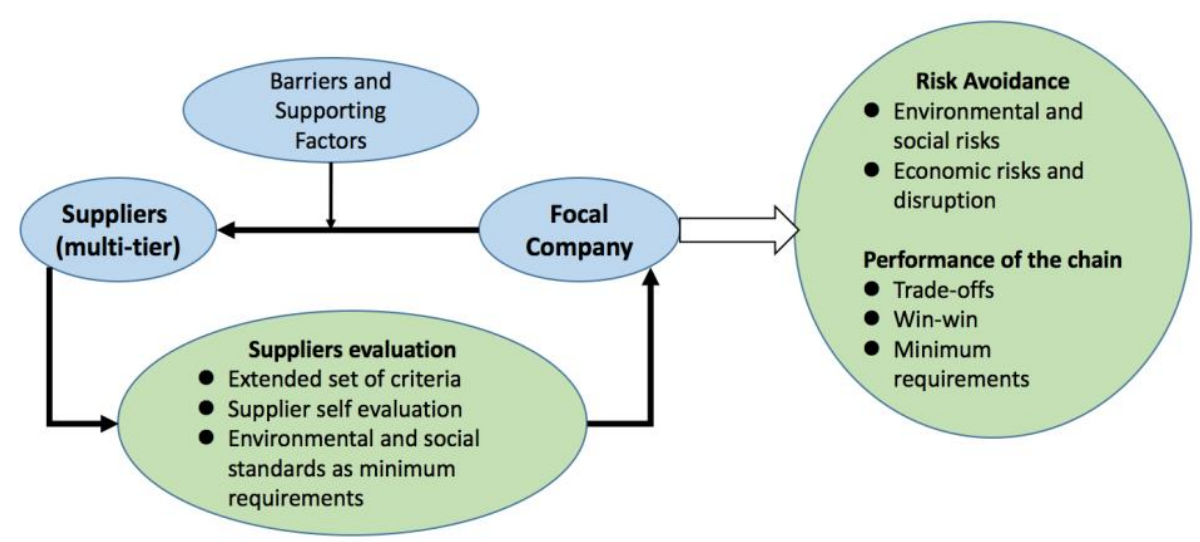

Figure 7. Framework of Sustainable supply chain performance and risk operation (Seuring and Mueller, 2008 [26]).

It can be seen from the above figures of two existing service supply chain sustainable management frameworks that TBL and sustainable service supply chain management are inseparable, but Hussian has only added the customer management aspects, which cannot highlight the importance of the end-customers' participating in the service supply chain. Meanwhile, Seuring only constructs a supply chain performance management framework from the perspective of risk aversion, without a corresponding sustainable description at the supply chain implementation level, which is precisely the most needed to fill the vacancy. Hence, in the theoretical aspect, it is necessary to explore the service supply chain management framework for the TBL aspect systematically. 


\section{A Framework of SSSCM Based on TBL}

\subsection{Service Supply Chain and Its Development}

The research on service supply chains in foreign countries started in 2000, and it is still in the immature stage. American scholar Lisa M. Ellram, in 2004 [12], published an article named "Understanding and Management of Service Supply Chain", marking the formal emergence of service supply chain research. Research on the application of the service supply chain industry has been carried out in recent years, mainly concentrated on property services, tourism services, and logistics services industries. The traditional manufacturing supply chain has some same characteristics with the service supply chain. For instance, its background lies in the professional trend and the development of core competitiveness, making outsourcing business inevitable; also, the main management contents include the supply, planning, logistics, demand, and so on. In general, the service supply chain members mainly include functional service providers, service integrators, and customers. In this chain, service integrators integrated functional service providers' service capabilities, and the providers are in charge of providing customers with integrated services. Integrators play an important role in the service supply chain, helping to match customers' needs with providers' services, while the providers are actual service providers and are in direct contact with customers. For example, Liu et al. (2013) [75], China's Yuan tong Express Logistics (Liu et al., 2015a) [76], and CH Robinson (Kuei et al., 2008) [77] integrate a number of logistics service providers and purchase transport capacity and storage capacity from them. In this way, providers can provide customers with systematic logistics services. However, service products have special characteristics such as labor-intensive, intangible, and tangible products, combined with non-storage, customer influence, and others, which are different from the manufacturing product. Thus, there are significant differences in the sustainable management between the service supply chain and the manufacturing supply chain.

In the past, most of the research on supply chains was based on the dual factors' view of supply chain management, but with the supply chain networked and being more complicated, the analysis of the dual perspective level is likely to lead the supply chain to lose opportunities in the competition tide. The ternary relation has become the smallest analysis unit in the competitive network and has received more attention in the present academic research. Some scholars have developed some related studies based on ternary relationships (Nair and Vidal, 2011) [78]. Finne and Holmstrom (2012) [79] have found that there is a "natural ternary" in the service supply chain by establishing a ternary application model, whereby the supplier can serve the supply chain; even the end-user relationship is controlled by the integrator. In the current background of the global purchasing and networking cooperation, only considering two members in a supply chain is a simple method, which has seriously been out of touch with reality in the perspective of duality. In the supply chain of ternary relation, if a conflict of interest happens between the two cooperative partners, the third party can act as a mediator to mediate the conflict between the two parts. Of course, there are also some certain risks in the ternary relation. For example, if one cooperative party treats another one in an improper way, it is not only injurious to their dual angles view, but also a damaged risk, which will become more and more visible to the third one in a ternary relationship (Wu and Choi, 2010) [80].

At present, with the development of the basic theory of relevant supply chain, the research of the product supply chain has been more mature. However, even though the research for the service supply chain starts relatively late, there exists great potential in the basic theory research on the service supply chain, based on a theoretical perspective of ternary.

\subsection{Main Sustainability Features of Service Supply Chain}

Sustainability in a service supply chain has its unique advantages in the competitive market. It can make a supply chain adapt and guide the requirement of the market long time continuously, and it can also bring more high-quality products to the consumers. Compared with sustainability in 
the manufacturing supply chain, the main features of sustainability in the service supply chain are shown in the following aspects.

First, since the customers influence the serving products greatly, the core enterprises in the service supply chain undertake the main social pressure, including pressure from the government (Dou and Sarkis, 2010 [81]; Kuo et al., 2010 [82]; Muduli et al., 2013 [83]) and from the customers (Yalabik and Fairchild, 2011) [84]. Moreover, they have to satisfy the customers from upstream and downstream and have to deal with social influence because of complaints (Kainuma and Tawara, 2006) [85].

Secondly, the production and provision of services are ongoing simultaneously, which leads to inseparable features of the service product. Additionally, the quality of service is hard to measure (Berry et al., 1985) [86]. More standard supplier controls are needed in the sustainable service supply chain. To the upstream suppliers, LCA is needed from the beginning to the end [46]. The requirement of the environmental protection will be improved greatly for the service providers. For instance, some online tourism commercial companies (such as China's Ctrip travel agency) have integrated global hotels, transport companies, and travel agencies to provide an integrated tourism service for the consumers. Some providers, such as hotels and transport companies, are required to decrease the damages to the DZR Ghost and protect the real rights and interests of consumers by, for example, using a regenerative resource to reduce the environmental damages.

Lastly, labor intensity in the service supply chain also makes the core enterprises attach importance to their responsibilities in society, especially the attention on the supply chain risk (Ciliberti et al., 2011) [87]. A service-oriented supply chain is needed to deal with problems from employees, such as poverty, unemployment, and medical treatments, to ensure that employees get their basic requirements. In such a service supply chain, every participant plays its own role, undertakes its own responsibility, and takes its own corrective actions when necessary.

\subsection{Sustainable Service Supply Chain Based on TBL}

Based on the analysis of existing sustainable manufacturing supply chain research in Section 4, we argue that TBL has been mostly applied in the manufacturing supply chain, which provides a helpful reference for constructing a sustainable service supply chain management framework. From the case described in the introduction, we know that TBL has a number of constraints regarding the service supply chain, which requires building a sustainable operational management framework. It is reasonable to take the characteristics of the service supply chain into account by considering the role of TBL in the manufacturing supply chain.

Because of the intangibility feature of the service, which makes the sustainable management of the service supply chain difficult, it is fortunate that TBL provides a clear direction for the management of the service supply chain. As emphasized by Brandenburg (2014) [41], Seuring and Mueller (2008) [26], and Hussian et al. (2015) [18], TBL and sustainable supply chain management are inseparable, both in the manufacturing and service supply chains.

Compared with manufacturing supply chains, the relationship among the participants in the service supply chain has become more complicated and various. In such a case, sustainable development can influence all the participants separately or reciprocally; the reciprocal effect makes us consider the ternary relational structure existing in the service supply chain, which is shown in Tables 6 and 7. 
Table 6. The stand-alone Impact of Sustainable Development on Service Supply Chain Participants.

\begin{tabular}{|c|c|c|c|}
\hline Bottom Line & Provider & $\begin{array}{l}\text { Core Enterprises } \\
\text { (Integrators) }\end{array}$ & Clients \\
\hline Environment & $\begin{array}{l}\text { Transport is the main } \\
\text { source of environmental } \\
\text { pollution, economic } \\
\text { bottom line is difficult } \\
\text { to compatible }\end{array}$ & $\begin{array}{l}\text { - Bear customers, } \\
\text { stakeholders } \\
\text { environment's pressure } \\
\text { and turn upstream }\end{array}$ & $\begin{array}{l}\text { Environmental awareness has } \\
\text { been improved, and pass it to the } \\
\text { upstream, which is the source of } \\
\text { pressure and stimulation } \\
\text { (Yalabik and Fairchild, 2011) [84] }\end{array}$ \\
\hline Society & $\begin{array}{l}\text { - Not the focus of the } \\
\text { public opinion } \\
\text { Belong to } \\
\text { marginalized enterprises }\end{array}$ & $\begin{array}{l}\text { - Undertake the entire } \\
\text { supply chain of public } \\
\text { opinion (Kainuma and } \\
\text { Tawara, 2006) [85] Divided } \\
\text { into internal and external }\end{array}$ & $\begin{array}{l}\text { - Spontaneous social } \\
\text { responsibility, and affect } \\
\text { the integrator }\end{array}$ \\
\hline Economy & $\begin{array}{l}\text { - } \quad \text { Mostly low-profit business } \\
\text { Messy and difficult to } \\
\text { achieve economies of scale } \\
\text { (Liu et al., 2015a) [76] }\end{array}$ & $\begin{array}{l}\text { Enterprise competitiveness } \\
\text { directly affects the } \\
\text { economic benefits } \\
\text { Enterprise size will also } \\
\text { determine the } \\
\text { economic benefits }\end{array}$ & $\begin{array}{l}\text { - Focus on long-term profits, meet } \\
\text { the bottom line requirements } \\
\text { (Eskandarpour, 2015) [59] }\end{array}$ \\
\hline
\end{tabular}

Table 7. Interaction between Sustainable Development and Service Supply Chain Participants Based on Ternary Theory.

\begin{tabular}{|c|c|c|c|}
\hline Bottom Line & Providers and Clients & $\begin{array}{c}\text { Core Enterprises } \\
\text { (Integrators) and Clients }\end{array}$ & Providers and Integrators \\
\hline Economy & $\begin{array}{l}\text { There is a financial } \\
\text { dependence relationship } \\
\text { (Choi and Wu, } 2009 \text { [88]) }\end{array}$ & $\begin{array}{l}\text { - } \quad \begin{array}{l}\text { Meet the requirements } \\
\text { of stakeholders }\end{array} \\
\text { - } \quad \text { Customer management } \\
\text { (Hussian et al., 2015) [18] }\end{array}$ & $\begin{array}{l}\text { - Higher implementation and } \\
\text { communication costs }\end{array}$ \\
\hline Environment & $\begin{array}{l}\text { Establish barriers to entry } \\
\text { for providers }\end{array}$ & $\begin{array}{l}\text { - Evolving to circular economy } \\
\text { (Eskandarpour, 2015) [59] }\end{array}$ & $\begin{array}{l}\text { Establish environmental } \\
\text { management system, } \\
\text { namely ISO14001 }\end{array}$ \\
\hline
\end{tabular}

\subsection{A Framework of SSSCM}

In the existing framework of SSSCM, the dual structure of the supply chain is mostly used. However, the relationship between buyers and sellers is affected not only by the internal structure of the dual structure, but also by the interactions among the three factors (Choi and $\mathrm{Wu}, 2009$ ) [88]. Thus, the research unit for the supply chain should now be ternary-based, rather than binary-based (Kim et al., 2008) [89]. Based on the above discussion and inspired from the manufacturing supply chain sustainable framework of Figure 4 (Brandenburg, 2015) [71], we summarize the following framework of sustainable supply chain management under the concept of ternary supply chain theory and the triple bottom line constraints.

As shown in Figure 8, triple bottom lines are still the service supply chain of sustainable management's criteria. The environment and society are the two cornerstones of the sustainable supply chain, and the economy is built on these two cornerstones. As the focal member in the supply chain, the service integrator will encourage his supplier and customer to achieve three wins in the supply chain based on the life cycle assessment and meeting social responsibility. 


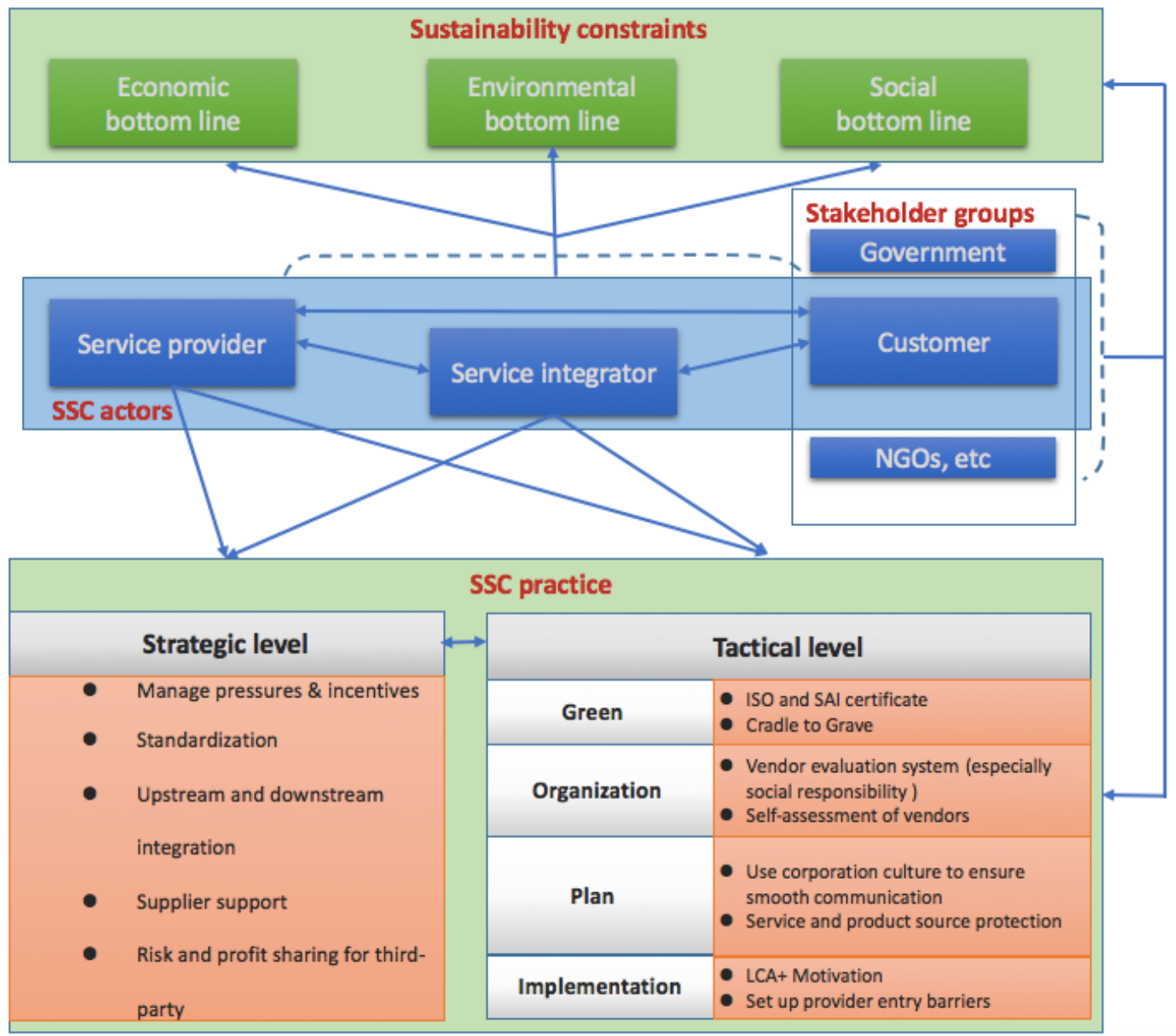

Figure 8. Service supply chain sustainable operations framework (Note: SSC represents service supply chain).

The ternary relationship is the core of the service supply chain enterprise relationship. In this relationship, the service integrator is not only concerned about customer needs and satisfaction, but is also concerned about service providers, in order to provide service and satisfaction. In ternary relationship, service providers in the supply chain maintain a high degree of contact with customers, which is a huge difference compared to previous supply chain theory. The relationship between the customer and the service provider will affect the integrator's management of the entire supply chain relationship. Service integrators, service providers, and customers all maintain a high degree of interaction and cooperation. In addition, other stakeholder groups such as government and non-government organization (NGO) will also make influences on the relationship and operations of service supply chain.

The ternary relationship in the service supply chain and the triple bottom line are closely interactive. On the one hand, the ternary subjects of the service supply chain must abide by the triple bottom line in order to achieve sustainable development. On the other hand, the triple bottom line will also restrict the ternary relationship of the service supply chain. During the different development periods of the economy and society, the triple bottom line will also change dynamically, and its restriction to the service supply chain changes, which will lead to changes in the ternary relationship.

The integrator, as the core enterprise, is the designer of the strategy layer and the strategy layer of the sustainable management of the service supply chain. In the strategic level, based on the triple bottom line, the ternary subject of the service supply chain carries out the standardization [52] in the environment and social dimensions and achieves the integration of upstream and downstream 
(Elkington, 1998) [90] to obtain the support of suppliers (Lewis et al., 2013) [91] and to ensure that integrators, suppliers, and customers share the common profits (Seuring and Mueller, 2008) [26].

Similarly, in the strategy layer, there are four important areas in sustainable service supply chain management, which are divided into green (Zsidisin, 2001 [92]), organizational (Porter and Van der Linde, 1995) [93], planning (McWilliams and Siegel, 2001) [94], and implementation (Beamon, 1999) [95]. The entire supply chain should share a set of ISO and SAI certification systems, from raw materials to the end of the life of the products, to achieve the green supervision and control. Integrators should monitor the upstream providers to establish a set of evaluation systems, especially their social responsibility, and to encourage providers to establish their own self-evaluation system. Integrators have to establish communication channels in the supply chain from the source to the end-market by the corporate culture in order to ensure the quality of services and products. Finally, based on the ternary relationship theory, the life cycle assessment of the whole supply chain must be established on the incentive policy, to set up barriers to the supplier's entrance. The supplier evaluation and supervision system for the social and economic dimension also need to be established so that the balance of the entire supply chain system is kept.

\subsection{Research Agenda of Sustainable Service Supply Chain}

The increasing global concern for sustainable development has brought unprecedented opportunities and challenges to the sustainable development of service supply chains. We believe that the future of supply chain sustainability research will comply with the triple bottom line and, at the same time, take the ternary theory on the impact of supply chain structure into account. Therefore, our proposed service supply chain sustainable operation framework has the following research agenda:

1. In the sustainable supply chain framework of service supply chains based on ternary theory, each individual is affected by the triple bottom line, and each individual is also an important component of the ternary relation. Therefore, the triple bottom line's interaction to the ternary relation and its mechanism of action will be worthy of further study.

2. In the framework of sustainable service supply chain management based on ternary theory, it is important to consider the constraints of the triple bottom line and to design the corresponding service supply chain strategy. These important strategies will include the interaction research of the standardization of services in the supply chain strategy, upstream and downstream supply chain relationship management, customer satisfaction and supplier support, supply chain risk, and profit-sharing tripartite issues, which all have important research value. In these studies, one must not only consider the interactions from the supply chain ternary participants, but also take into account the constraints and impacts of TBL on these strategic designs.

3. On the strategic level of service supply chain sustainable operation, some important operational strategies are still worthy of in-depth discussion. First, because of the intangible characteristics of service products, it is not easy for a service supply chain to realize the green supply chain compared with the manufacturing supply chain. Therefore, it is urgent to construct corresponding green operation requirements according to the characteristics of the service products. The whole service supply chain's green operation and management system's construction are worthy of in-depth study. Secondly, the coordination framework of the sustainable service supply chain based on a ternary relationship is also worthy of further study. Because it will break the previous solutions, which consider the service integrator to be the center of supply chain, a multi-agent structure will be adopted to design a supply chain that leads to a new demand for a coordination framework. Thirdly, in the operation of SSSCM, we must take into account the social responsibility and economic responsibility under the dual constraints of organizational relationship management. Lastly, consideration of the ternary relationship under service supply chain planning requirements and incentive-oriented life cycle assessments, along with provider barrier settings, are worthy of an in-depth study as well. 


\section{Conclusions}

Sustainable development is the inevitable choice of the development of human society. Supply chain management will comply with the trend of sustainable development. Compared to the sustainability of the manufacturing supply chain, we find that some of the characteristics of the service industry, such as customer influence, immeasurability, and labor intensity, affect the implementation of the TBL in service supply chains. The existence of ternary relations in service supply chains will also affect the interaction of supply chain participants. Accordingly, from the perspective of ternary theory, we propose a framework for the sustainable operation of service supply chains. In this framework, the TBL has a close relationship with the ternary relationship of supply chains and has different effects at the strategic level and the operational level.

This paper reviews the literature on sustainable supply chain development based on the TBL in the last decade. The paper analyzes three typical sustainable development frameworks in the manufacturing supply chain, including the work of Ageron (2012) [70], Amini (2014) [74], Brandenburg (2015) [73] and Seuring (2008) [26], which exist in the service supply chain. The main features of these frameworks are combined. The main contribution of our research is that we propose a new service supply chain sustainable operation framework. Differing from Brandenburg (2015) [71], who considered the sustainability of the supply chain from a single provider perspective, we believe that providers, integrators, and end users are interconnected in the context of a sustainable service supply chain system. Similarly, Seuring (2008) [26] only builds a core business-oriented sustainable service supply chain management framework from the perspective of risk control and performance management. On basis of Seuring (2008) [26], the strategic and operational considerations are added in our paper and a complete framework of SSSCM is obtained under the constraints of TBL. In addition, several new research agendas are proposed. We believe that the internal and external mechanisms of ternary relations are worthy of further study. Different from the agenda proposed by Roth and Menor (2003) [8], we propose future research agendas at the strategic and tactical levels, from the perspective of the sustainability of the service supply chain, which will stand as a positive guide for future supply chain sustainability research.

The limitation of this paper is that we only study the sustainable service supply chain based on the ternary theory and TBL. However, the service supply chain may face many new external environments. New technical, managerial, and economic features will be included in the future studies. For example, under the influence of the global economy, emerging markets, and technologies, the sustainable management of service supply chains will become more diversified. The future research on sustainable service supply chain management and operations can combine with more external environment changes and new research opportunities to carry out more framework research in order to adapt to more realistic situations.

Acknowledgments: This research is supported by the National Natural Science Foundation of China (Grant No. 71372156, 71672121), sponsored by Independent Innovation Foundation of Tianjin University. The reviewers' comments are also highly appreciated.

Author Contributions: Weihua Liu designed the research. Weihua Liu, Enze Bai, Liwei Liu and Wanying Wei performed the research and wrote the paper. All authors read and approved the final manuscript.

Conflicts of Interest: The authors declare no conflict of interest.

\section{References}

1. Powell, D. ERP systems in lean production: New insights from a review of lean and ERP literature. Int. J. Oper. Prod. Manag. 2013, 33, 1490-1510. [CrossRef]

2. Beheshti, H.M.; Blaylock, B.K.; Henderson, D.A.; Lollar, J.G. Selection and critical success factors in successful ERP implementation. Competitiveness Rev. 2014, 24, 357-375. [CrossRef]

3. Vezzetti, E.; Alemanni, M. Supporting product development in the textile industry through the use of a product lifecycle management approach: A preliminary set of guidelines. Int. J. Adv. Manuf. Technol. 2015, 79, 1493-1504. [CrossRef] 
4. Mesihovic, S.; Malmqvist, J.; Pikosz, P. Product data management system-based support for engineering project management. J. Eng. Des. 2004, 15, 389-403. [CrossRef]

5. Vezzetti, E.; Alemanni, M.; Morelli, B. New product development (NPD) of 'family business' dealing in the luxury industry: Evaluating maturity stage for implementing a PLM solution. Int. J. Fash. Des. Technol. Educ. 2016. [CrossRef]

6. Masters, J.M.; Pohlen, T.L. Evolution of the Logistics Profession. In The Logistics Handbook; Free Press: New York, NY, USA, 1994.

7. Langley, C.J. The evolution of the logistics concept. J. Bus. Logist. 1986, 7, 1-13.

8. Roth, A.V.; Manor, L.J. Insights into service operations management: A research agenda. Prod. Oper. Manag. 2003, 12, 145-164. [CrossRef]

9. Linton, J.D.; Klassen, R.; Jayaraman, V. Sustainable Supply Chains: An Introduction. J. Oper. Manag. 2007, 42, 451-469. [CrossRef]

10. Seuring, S.; Muller, M. Core issues in sustainable supply chain management-A delphi study. Bus. Strategy Environ. 2008, 17, 455-466. [CrossRef]

11. Carter, C.R.; Rogers, D.S. A framework of sustainable supply chain management: Moving toward new theory. Int. J. Phys. Distrib. Logist. Manag. 2008, 38, 360-387. [CrossRef]

12. Ellram, L.M.; Tate, W.L.; Billington, C. Understanding and Managing the Service Supply Chain. J. Supply Chain Manag. 2004, 40, 17-32. [CrossRef]

13. Wang, Y.L.; Wallace, S.W.; Shen, B.; Choi, T.M. Service supply chain management: A review of operational models. Eur. J. Oper. Res. 2015, 247, 685-698. [CrossRef]

14. Baltacioglu, T.; Ada, E.; Kaplan, M.D.; Yurt, O.; Kaplan, Y.C. A new framework for service supply chains. Serv. Ind. J. 2007, 27, 105-124. [CrossRef]

15. Demirkan, H.; Cheng, H. The risk and information sharing of application services supply chain. Eur. J. Oper. Res. 2008, 187, 765-784. [CrossRef]

16. Sampson, S.E.; Spring, M. Customer roles in service supply chains and opportunities for innovation. J. Supply Chain Manag. 2012, 48, 30-50. [CrossRef]

17. Liu, W.; Liang, Z.; Ye, Z.; Liu, L. The optimal decision of customer order decoupling point for order insertion scheduling in logistics service supply chain. Int. J. Prod. Econ. 2016, 175, 50-60. [CrossRef]

18. Hussain, M.; Khan, M.; Al-Aomar, R. A framework for supply chain sustainability in service industry with CFA. Renew. Sustain. Energy Rev. 2015, 55, 1301-1312. [CrossRef]

19. Zhao, M. 27 Logistic Vehicles Are Reported to Be Emission Exceeded. Available online: http://news.163. com/14/0530/05/9TFJCLI800014AED.html (accessed on 16 January 2017). (In Chinese)

20. Fast Hotel Washed Out White Bed Sheets with Caustic Soda Blending Detergent. Available online: http:/ / www.bj.xinhuanet.com/bjyw/yqphb/2016-04/18/c_1118650311.htm (accessed on 16 January 2017). (In Chinese)

21. Tourism B2B Capital Chain Rupture Run Case Appear Frequently: Following Yoke and Daily Trip, Chiyu Tourism Company Frankly Make Acknowledgement of a Debt 270 Million Yuan. Available online: http: / / mt.sohu.com/20161111/n472958126.shtml (accessed on 16 January 2017). (In Chinese)

22. Mayring, P. Quanlitative Inhaltanalyse-Grundlagen und Tchniken, 8th ed.; Beltz Verlag: Weinheim, Germany, 2003.

23. Reim, W.; Paride, V.; Qrtqvist, D. Product-Service System (PSS) business models and tactics-A systematic literature review. J. Clean. Prod. 2015, 97, 61-75. [CrossRef]

24. Agrawal, S.; Singh, R.K.; Murtaza, Q. A literature review and perspectives in reverse logistics. Resour. Conserv. Recycl. 2015, 97, 76-92. [CrossRef]

25. Lotfizadeh, A.D.; Edwards, T.L.; Poling, A. Motivating operations in the Journal of Organizational Behavior Management: Review and discussion of relevant articles. J. Organ. Behav. Manag. 2014, 34, 69-103.

26. Seuring, S.; Mueller, M. From a literature review to a conceptual framework for sustainable supply chain management. J. Clean. Prod. 2008, 16, 1699-1710. [CrossRef]

27. Kannegiesser, M.; Günther, H.O.; Autenrieb, N. The Time-to-Sustainability Optimization Strategy for Sustainable Supply Network Design. J. Clean. Prod. 2015, 108, 451-463. [CrossRef]

28. Helin, S.; Babri, M. Travelling with a code of ethics: A contextual study of a Swedish MNC auditing a Chinese supplier. J. Clean. Prod. 2014, 107, 41-53. [CrossRef] 
29. Sengupta, K.; Heiser, D.R.; Cook, L.S. Manufacturing and Service Supply Chain Performance: A Comparative Analysis. J. Supply Chain Manag. 2006, 42, 4-15. [CrossRef]

30. Zhou, M.; Park, T.; Yi, J. Commonalities and Differences between Service and Manufacturing Supply Chains: Combining Operations Management Studies with Supply Chain Management. Calif. J. Oper. Manag. 2009, 7, 136-143.

31. Anderson, E.G.; Mortice, D.J.; hmdeen, G. The "Physics" of Capacity and Backlogmangement in Service and Custom Manufacturing Supply Chains. Syst. Dyn. Rev. 2005, 21, 217-247. [CrossRef]

32. Wei, Y.; Hu, Q.; Xu, C. Ordering, pricing and allocation in a service supply chain. Int. J. Prod. Econ. 2013, 144, 590-598. [CrossRef]

33. Liu, W.; Wang, S.; Chen, L. The role of control power allocation in service supply chains: Model analysis and empirical examination. J. Purch. Supply Manag. 2017, in press. [CrossRef]

34. Murphy, P.R.; Poist, R.F.; Braunschweig, C.D. Management of environmental issuesin logistics: Current status and future potential. Transp. J. 1994, 34, 48-56.

35. Ferdows, K. Shaping global operations. J. Globlization Competitiveness Governability 2009, 3, 136-148.

36. Seuring, S. A review of modeling approaches for sustainable supply chain management. Decis. Support Syst. 2013, 54, 1513-1520. [CrossRef]

37. You, F.; Wang, B. Life cycle optimization of biomass-to-liquid supply chains with distributed centralized processing networks. Ind. Eng. Chem. 2011, 50, 10102-10127. [CrossRef]

38. Genovese, A.; Acquaye, A.A.; Figueroa, A.; Koh, S.C.L. Sustainable supply chain management and the transition towards a circular economy: Evidence and some applications. Omega 2015, 66, 344-357. [CrossRef]

39. Hasan, M. Sustainable Supply Chain Management Practices and Operational Performance. Am. J. Ind. Bus. Manage. 2013, 3, 42-48. [CrossRef]

40. Omer, A.M. Energy, environment and sustainable development. Renew. Sustain. Energy Rev. 2008, 12, 2265-2300. [CrossRef]

41. Brandenburg, M.; Govindan, K.; Sarkis, J.; Seuring, S. Quantitative models for sustainable supply chain management: Developments and directions. Eur. J. Oper. Res. 2014, 233, 299-312. [CrossRef]

42. Beske, P.; Land, A.; Seuring, S. Sustainable supply chain management practices and dynamic capabilities in the food industry: A critical analysis of the literature. Int. J. Prod. Econ. 2014, 152, 131-143. [CrossRef]

43. SAI (2008). SA8000: Social Accountability International. New-York. Available online: http://www. sa-intl.org/index.cfm?fuseaction=Page.viewPage\&pageId=937\&parentID=479\&nodeID=1 (accessed on 13 April 2016).

44. European Commission (2009). EMAS-The European Eco-Management and AuditScheme, European Union, Belgium. Available online: http://ec.europa.eu/environment/emas/index_en.htm (accessed on 13 April 2016).

45. Carroll, A.B. A three-dimensional conceptual model of corporate performance. Acad. Manag. Rev. 1979, 4, 497-505.

46. Clarkson, M. A stakeholder framework for analyzing and evaluating corporate social performance. Acad. Manag. Rev. 1995, 20, 42-56.

47. Wood, D.J. Corporate social performance revisited. Acad. Manag. Rev. 1991, 16, 691-718.

48. Berry, M.A.; Rondinelli, D.A. Proactive corporate environmental management: A new industrial revolution. Acad. Manag. Perspect. 1998, 12, 38-50. [CrossRef]

49. Azapagic, A.; Perdan, S. Indicators of sustainable development for industrya general framework. Process Saf. Environ. 2000, 78, 243-261. [CrossRef]

50. Carter, C.R.; Jennings, M.M. Logistics social responsibility: An integrative framework. J. Bus. Logist. 2002, 23, 145-178. [CrossRef]

51. Hutchins, M.J.; Sutherland, J.W. An exploration of measures of social sustainability and their application to supply chain decisions. J. Clean. Prod. 2008, 16, 1688-1698. [CrossRef]

52. Matos, S.; Hall, J. Integrating sustainable development in the supply chain: The case of life cycle assessment in oil and gas and agricultural biotechnology. J. Oper. Manag. 2007, 25, 1083-1102. [CrossRef]

53. O'Connor, M.; Spangenberg, J.H. A methodology for CSR reporting: Assuring a representative diversity of indicators across stakeholders, scales, sites and performance issues. J. Clean. Prod. 2008, 16, 1399-1415. [CrossRef] 
54. Foerstl, K.; Reuter, C.; Hartmann, E.; Blome, C. Managing supplier sustainability risks in a dynamically changing environment—Sustainable supplier management in the chemical industry. J. Purch. Supply Manag. 2010, 16, 118-130. [CrossRef]

55. Gimenez, C.; Sierra, V.; Rodon, J. Sustainable operations: Their impact on the triple bottom line. Int. J. Prod. Econ. 2012, 140, 149-159. [CrossRef]

56. Castka, P.; Balzarova, M. ISO 26000 and supply chains-On the diffusion of the social responsibility standard. Int. J. Prod. Econ. 2008, 111, 274-286. [CrossRef]

57. Rubio, S.; Corominas, A. Optimal manufacturing-remanufacturing policiesin a lean production environment. Comput. Ind. Eng. 2008, 55, 234-242. [CrossRef]

58. Tseng, M.; Divinagracia, L.; Divinagracia, R. Evaluating firm's sustainable Production indicators in uncertainty. Comput. Ind. Eng. 2009, 57, 1393-1403. [CrossRef]

59. Eskandarpour, M.; Pierre, D.; Joe, M.; Olivier, P. Sustainable supply chain network design: An optimization-oriented review. Omega 2015, 54, 11-32. [CrossRef]

60. Jorgensen, A. SocialLCA-A way ahead? Int. J. Life Cycle Assess. 2013, 18, 296-299. [CrossRef]

61. Grimm, J.H.; Hofstetter, J.S.; Sarkis, J. Critical factors for sub-supplier management: A sustainable food supply chains perspective. Int. J. Prod. Econ. 2014, 152, 159-173. [CrossRef]

62. Ramos, T.R.P.; Gomes, M.I.; Barbosa-Póvoa, A.P. Planning a sustainable reverse logistics system: Balancing costs with environmental and social concerns. Omega 2014, 48, 60-74. [CrossRef]

63. Wood, L.C. Investigating the formation of service supply chains. Serv. Ind. J. 2015, 35, 5-23.

64. Hahn, R. ISO 26000 and the standardization of strategic management processes for sustainability and corporate social responsibility. Bus. Strategy Environ. 2013, 22, 442-455. [CrossRef]

65. Mori, K.; Christodoulou, A. A Review of sustainability indices and indicators: Towards a new City Sustainability Index (CSI). Environ. Impact Assess. Rev. 2012, 32, 94-106. [CrossRef]

66. Chen, L.; Olhager, J.; Tang, O. Manufacturing facility location and sustainability: A literature review and research agenda. Int. J. Prod. Econ. 2014, 149, 154-163. [CrossRef]

67. Ciliberti, F.; Pontrandolfo, P.; Scozzi, B. Logistics Social Responsibility: Standard Adoption and Practices in Italian Companies. Int. J. Prod. Econ. 2008, 113, 88-106. [CrossRef]

68. Hassini, E.; Surti, C.; Searcy, C. A literature review and a case study of sustainable supply chains with a focus on metrics. Int. J. Prod. Econ. 2012, 140, 69-82. [CrossRef]

69. Wu, Z.; Pagell, M. Balancing priorities: Decision-making in sustainable supply chain management. J. Oper. Manag. 2011, 29, 577-590. [CrossRef]

70. Ageron, B.; Gunasekaran, A.; Spalanzani, A. Sustainable supply management: An empirical study. Int. J. Prod. Econ. 2012, 140, 168-182. [CrossRef]

71. Brandenburg, M.; Rebs, T. Sustainable supply chain management: A modeling perspective. Ann. Oper. Res. 2015, 229, 213-252. [CrossRef]

72. Chardine-Baumann, E.; Botta-Genoulaz, V. A framework for sustainable performance assessment of supply chain management practices. Comput. Ind. Eng. 2014, 76, 138-147. [CrossRef]

73. Winkler, H. Closed-loop production systems-A sustainable supply chain approach. J. Manuf. Sci. Technol. 2011, 4, 243-246. [CrossRef]

74. Amini, M.; Bienstock, C.C. Corporate sustainability: An integrative definition and framework to evaluate corporate practice and guide academic research. J. Clean. Prod. 2014, 76, 12-19. [CrossRef]

75. Liu, W.H.; Ge, M.Y.; Yang, D.J. An order allocation model in a two-echelon logistics service supply chain based on the rational expectations equilibrium. Int. J. Prod. Res. 2013, 51, 3963-3976. [CrossRef]

76. Liu, W.; Xie, D.; Liu, Y.; Liu, X.Y. Service capability procurement decision in logistics service supply chain: A research under demand updating and quality guarantee. Int. J. Prod. Res. 2015, 53, 488-510. [CrossRef]

77. Kuei, C.-H.; Madu, C.N.; Lin, C. Developing global supply chain quality management systems. Int. J. Prod. Res. 2011, 49, 4457-4481. [CrossRef]

78. Nair, A.; Vidal, J.M. Supply network topology and robustness against disruptions-An investigation using multi-agent model. Int. J. Prod. Res. 2011, 49, 1391-1404. [CrossRef]

79. Finne, M.; Holmström, J. A manufacturer moving upstream: Triadic colla ration for service delivery. Supply Chain Manag. Int. J. 2012, 18, 21-33. [CrossRef]

80. Wu, Z.; Choi, T.Y.; Rungtusanatham, M.J. Supplier-supplier relation ships in buyer-supplier-supplier triad s: Implications for supplier performance. J. Oper. Manag. 2010, 28, 115-123. [CrossRef] 
81. Dou, Y.; Sarkis, J. A joint location and outsourcing sustainability analysis for a strategic offshoring decision. Int. J. Prod. Res. 2010, 48, 567-592. [CrossRef]

82. Kuo, R.J.; Wang, Y.C.; Tien, F.C. Integration of artificial neural network and MADA methods forgreen supplier selection. J. Clean. Prod. 2010, 18, 1161-1170. [CrossRef]

83. Muduli, K.; Govindan, K.; Barve, A.; Geng, Y. Barriers to green supplychain management in Indian mining industries: A graph theoretic approach. J. Clean. Prod. 2013, 47, 335-344. [CrossRef]

84. Yalabik, B.; Fairchild, R.J. Customer, regulatory, and competitive pressure as drivers of environmental innovation. Int. J. Prod. Econ. 2011, 131, 519-527. [CrossRef]

85. Kainuma, Y.; Tawara, N. A multiple attribute utility theory approach to lean and green supply chainmanagement. Int. J. Prod. Econ. 2006, 101, 99-108. [CrossRef]

86. Berry, L.L. A Conceptual Model for Service Quality and Its Implication for Future Research. J. Mark. 1985, $49,41-50$.

87. Ciliberti, F.; Haan, J.D.; Groot, G.D.; Pontrandolfo, P. CSR codes and the principal-agent problem in supply chains: Four case studies. J. Clean. Prod. 2011, 19, 885-894. [CrossRef]

88. Choi, T.Y.; Wu, Z. Triads in supply networks: Theorizing buyer-supplier-supplier relationships. J. Supply Chain Manag. 2009, 45, 8-25. [CrossRef]

89. Kim, H.G.; Moon, J.; Choi, C.Y. A Study on the Factors of Supply Chain Integration Influencing Corporate Performance-Based on the comparison of Large and Small-Medium Size Enterprises. E-Bus. Stud. 2008, 9, 3-25. (In Korean)

90. Elkington, J. Cannibals with forks: The triple bottom line of 21st century business. Environ. Qual. Manag. 1998, 8, 37-51. [CrossRef]

91. Lewis, B.M.; Erera, A.L.; Nowak, M.A.; White, C.C. Managing inventory in global supply chains facing port-of-entry disruption risks. Transp. Sci. 2013, 47, 162-180. [CrossRef]

92. Zsidisin, G.A.; Siferd, S.P. Environmental purchasing: A framework for theory development. Eur. J. Purch. Supply Manag. 2001, 7, 61-73. [CrossRef]

93. Porter, M.E.; Claas, V.D.L. Toward a New Conception of the Environment-Competitiveness Relationship. J. Econ. Perspect. 1995, 9, 97-118. [CrossRef]

94. Mcwilliams, A.; Siegel, D. Corporate Social Responsibility: A Theory of the Firm Perspective. Acad. Manag. Rev. 2001, 26, 117-127.

95. Beamon, B.M. Measuring supply chain performance. Int. J. Oper. Prod. Manag. 1999, 19, 275-292. [CrossRef] 